\title{
Bleeding diathesis due to a collagen receptor defect
}

INSERM

\section{Source}

INSERM. (1999). Orphanet: an online rare disease and orphan drug data base. Bleeding diathesis due to a collagen receptor defect. ORPHA:73271

Bleeding diathesis due to a collagen receptor defect is a rare, genetic coagulation disorder characterized by a mild to moderate bleeding tendency due to impaired platelet activation and aggregation in response to collagen, or impaired platelet-vessel wall interaction, resulting from a collagen receptor defect. Patients manifest with ecchymoses, epistaxis, menorrhagia, and/or post-traumatic and post-surgery bleeding complications. Laboratory analysis reveals prolonged bleeding time and, occasionally, mild thrombocytopenia. 